\title{
Yield and Quality of Aonla (Emblica officinalis Gaertn.) as Influenced by Foliar Application of Different Sources of Potassium with and without Urea Spray
}

\author{
Jagendra Pratap Singh, Saurabh Tomar", Mahendra Chaudhary and \\ Jayant Kumar Maurya
}

\author{
Department of Horticulture, Chandra Shekhar Azad University of Agriculture and Technology \\ Kanpur 208002 (U.P.) India \\ *Corresponding author
}

A B S T R A C T

\begin{abstract}
Keywords
Aonla, Foliar spray

of nutrients,

Potassium sources,

Urea, Yield,

Quality.

Article Info

Accepted:

19 July 2017

Available Online:

10 September 2017 Gaertn.) cv. Chakaiya at Kumarganj, Faizabad (Uttar Pradesh) during the year 2013-14. In all, 8 treatments of foliar nutrients application viz. control (water spray), $\mathrm{K}_{2} \mathrm{SO}_{4}(2 \%)$, $\mathrm{KCL}(2 \%), \mathrm{KNO}_{3}(2 \%), \mathrm{K}_{2} \mathrm{SO}_{4}(2 \%)+$ urea (2\%), $\mathrm{KCL}(2 \%)+$ urea $(2 \%), \mathrm{KNO}_{3}(2 \%)+$ urea $(2 \%)$ and urea alone $(2 \%)$ were tasted in RBD replicated thrice. On total 24 trees of Aonla, manures and fertilizers were applied as per recommended schedule for aonla plantation. The treatments were applied twice i.e. after fruit set and at fruit bud development stages. The results obtained revealed that the treatment foliar application of $\mathrm{H}_{2} \mathrm{SO}_{4}+$ urea recorded minimum percent fruit drop, maximum per cent fruit retention, biggest fruit size, highest fruit weight, maximum pulp: stone ratio and TSS content in pulp, minimum acidity content, maximum vitamin ' $\mathrm{C}$ ' content and percentage of total sugars and significantly highest fruit yield per tree among all treatments tried. It was followed by the treatment foliar application of $\mathrm{KCL}+$ urea in all fruit characters including yield. Lone spraying of $\mathrm{K}_{2} \mathrm{SO}_{4}$, $\mathrm{KCL}$ or $\mathrm{KNO}_{3}$ could not prove significant superiority over control in most of the cases while urea alone spray was found significantly superior over control in almost all observations including fruit yield.
\end{abstract}

An investigation was carried out on 15 years old plantation of Aonla (Emblica officinalis

\section{Introduction}

Aonla (Emblica officinalis Gaertn.) is one of the most nutritious fruits and second richest source of vitamin ' $C$ ' after Barbados cherry. It is also a fair source of carotene, Thiamine, Riboflavin, carbohydrates and minerals like iron, phosphorus, calcium and magnesium. Among the commercial grown varieties, 'chakaiya' is the most popular due to its high bearing potential, late fruit maturity, medium fruit size, rich in vitamin ' $\mathrm{C}$ ' content and prolonged shelf life. However, the severe fruit dropping, poor fruit yield and incidence of nutritional fruit disorders have been observed in old Aonla plantation/ senile orchards which resulted in declining the cultivated area of Aonla in commercial growing fruit belts of eastern Uttar Pradesh. Foliar application of nutrients particularly $\mathrm{N}$ and $\mathrm{K}$ have been found more effective in improving the flowering, fruit set, fruit yield and fruit quality in Aonla crop (Singh et al., 2009). In this view, the present study was undertaken to 
increase the yield and quality of Aonla fruits with the help of foliar application of potassium and urea.

\section{Materials and Methods}

An investigation was carried out on 15 years old plantation of Aonla cv. Chakaiya at main experiment station, Department of Horticulture, N.D. University of Agric. And Tech., Kumarganj, Faizabad (Uttar Pradesh) during the year 2013-14. The 24 Aonla trees having uniform growth were selected randomly for the study. The cultural operations and basal application of manures and fertilizers were applied as per recommended schedule for Aonla plantation. In all 8 treatments viz., to control (waterspray), $\mathrm{T}_{1}-\mathrm{K}_{2} \mathrm{SO}_{4}$ (2\% spray), $\mathrm{T}_{2}-\mathrm{KCL}(2 \%$ spray), $\mathrm{T}_{3}-\mathrm{KNO}_{3}$ (2\% spray), $\mathrm{T}_{4}-\mathrm{K}_{2} \mathrm{SO}_{4}(2 \%)$ + urea $(2 \%), \mathrm{T}_{5}-\mathrm{KCL}(2 \%)+$ urea $(2 \%), \mathrm{T}_{6^{-}}$ $\mathrm{KNO}_{3}(2 \%)+$ urea $(2 \%)$, spray and $\mathrm{T}_{7}$-urea ( $2 \%$ spray) were tested in complete randomized block design using 3 replications. The foliar spray of nutrients as per treatment was applied twice after fruit set.

First spray was done during second week of April, 2013 and second spray was followed during third week of June, 2013 at the time of fruit bud development stage. Spraying of material was done using as pee pneumatic foot sprayer fitted with nozzle. In each spraying, 10 litre solute material per tree as per treatment was used. The observations on each tree were recorded for fruiting behaiviour, fruit size, fruit weight, pulp: stone ratio and fruit yield per tree. Sampled fruits from each tree were analyzed chemically for recording their quality in terms of Total soluble solids, acidity, Ascorbic acid (Vitamin ' $\mathrm{C}$ '), reducing, non-reducing and total sugar. Whole data were analysed character wise by using standard statistical method suggested by Panse and Sukhatme (1985).

\section{Results and Discussion}

The data presented in Table 1 revealed that foliar application of nutrients reduced fruit drop and increased fruit retention as compared to control but significance of treatments varied. Dual spray of potassium + urea in all cases reduced fruit drop significantly compared to control but single spray of only potassium irrespective of source or urea Alone could not reduce fruit drop significantly as compared to control. In case of fruit retention, all treatments of nutrients spray except $\mathrm{KNO}_{3}(2 \%)$, increased fruit retention significantly over control.

Among those, $\mathrm{K}_{2} \mathrm{SO}_{4}+$ urea spray being at par with $\mathrm{KCL}+$ urea spray, recorded significantly higher fruit retention than all other treatments. It is thus proved from these results that the treatment of $\mathrm{K}_{2} \mathrm{SO}_{4}$ +urea spray was most effective in minimizing the fruit drop and in maximizing the fruit retention among all treatments tasted. It was followed by the treatment of $\mathrm{KCL}+$ urea spray in fruit drop and retention.

The best performance of $\mathrm{K}_{2} \mathrm{SO}_{4}+$ urea spray might be the combined beneficial effect of potassium, sulphur and nitrogen on fruit retention. These results are in accordance to the findings of Khan et al., (2009).

\section{Physical characters of fruits}

Foliar application of only potassium sources though improved fruit characters over control but margin of increase was not found significant in any case (Table-1). The combined spray of potassium + urea irrespective of sources being at par improved almost all physical characters of fruit significantly over control and also over other treatments. Fruit weight which is the resultant of overall fruit development was recorded highest of $35.40 \mathrm{~g}$ under $\mathrm{K}_{2} \mathrm{SO}_{4}+$ urea spray followed by $35.10 \mathrm{~g}$ under $\mathrm{KCL}+$ urea spray 
treatment. These figures were found to be 4.58 , 5.51, 6.63, 6.63, 8.76, 8.76 and $12.03 \%$ higher; and $3.69,4.62,5.72,5.72,7.83$ and $11.08 \%$ higher over fruit weights recorded under $\mathrm{KNO}_{3}$ + urea, urea alone, $\mathrm{K}_{2} \mathrm{SO}_{4}$ alone, KCL alone, $\mathrm{KNO}_{3}$ alone spray and control, respectively. Pulp: stone ratio also showed almost similar trend under different treatments. Better performance of $\mathrm{K}_{2} \mathrm{SO}_{4}+$ urea and $\mathrm{KCL}$ +urea spray treatments might be due to supply of sulphur, chlorine and nitrogen along with potassium. These nutrients together might have played important beneficial role in proper development of Aonla fruits. These results corroborate to the findings reported by Singh et al., (2009).

Table.1 Effect of different sources of potassium without and with urea on physical characters of Aonla fruits

\begin{tabular}{|c|c|c|c|c|c|c|c|c|}
\hline Treatments & $\begin{array}{c}\text { Fruit } \\
\text { drop } \\
(\%) \\
\end{array}$ & $\begin{array}{c}\text { Fruit } \\
\text { retentio } \\
\text { n }(\%)\end{array}$ & $\begin{array}{c}\text { Fruit } \\
\text { length } \\
(\mathrm{cm})\end{array}$ & $\begin{array}{c}\text { Fruit } \\
\text { width } \\
\text { (cm) } \\
\end{array}$ & $\begin{array}{c}\text { Fruit } \\
\text { weight } \\
\text { (g) } \\
\end{array}$ & $\begin{array}{c}\text { Pulp } \\
\text { weight } \\
\text { (g) } \\
\end{array}$ & $\begin{array}{c}\text { Stone } \\
\text { weight } \\
\text { (g) }\end{array}$ & $\begin{array}{l}\text { Pulp } \\
\text { stone } \\
\text { ratio } \\
\end{array}$ \\
\hline Control (water spray) & 82.4 & 17.60 & 2.75 & 3.10 & 31.60 & 28.70 & 2.90 & 9.90 \\
\hline $\mathrm{K}_{2} \mathrm{SO}_{4}(2 \%$ spray $)$ & 79.0 & 21.00 & 2.85 & 3.25 & 33.20 & 30.36 & 2.84 & 10.69 \\
\hline KCL (2\% spray) & 77.8 & 22.20 & 2.90 & 3.33 & 33.20 & 30.45 & 2.75 & 11.07 \\
\hline $\mathrm{KNO}_{3}(2 \%$ spray $)$ & 79.7 & 20.30 & 2.80 & 3.22 & 32.55 & 29.70 & 2.85 & 10.42 \\
\hline $\mathrm{K}_{2} \mathrm{SO}_{4}(2 \%)+\operatorname{urea}(2 \%)$ & 70.8 & 29.20 & 3.40 & 3.90 & 35.40 & 32.93 & 2.47 & 13.33 \\
\hline $\operatorname{KCL}(2 \%)+$ urea $(2 \%)$ & 72.7 & 27.30 & 3.30 & 3.80 & 35.10 & 32.47 & 2.63 & 12.35 \\
\hline $\mathrm{KNO}_{3}(2 \%)+$ urea $(2 \%)$ & 74.9 & 25.10 & 3.25 & 3.74 & 33.85 & 31.15 & 2.70 & 11.54 \\
\hline Urea (2\% spray) & 76.0 & 24.00 & 3.00 & 3.45 & 33.55 & 30.80 & 2.75 & 11.20 \\
\hline S. Em. \pm & 2.14 & 1.09 & 0.07 & 0.08 & 0.65 & 0.79 & 0.06 & 0.31 \\
\hline C.D. $(\mathrm{P}=0.05)$ & 6.49 & 3.32 & 0.22 & 0.24 & 1.96 & 2.41 & 0.18 & 0.94 \\
\hline
\end{tabular}

Table.2 Effect of different sources of potassium without and with urea on quality parameters of Aonla fruits

\begin{tabular}{|c|c|c|c|c|c|c|c|c|c|}
\hline \multirow[t]{2}{*}{ Treatments } & \multirow{2}{*}{$\begin{array}{c}\text { Total } \\
\text { soluble } \\
\text { solids } \\
(\%)\end{array}$} & \multirow[t]{2}{*}{$\begin{array}{c}\text { Acidity } \\
(\%)\end{array}$} & \multirow{2}{*}{$\begin{array}{c}\text { Red. } \\
\text { Sugars } \\
(\%)\end{array}$} & \multirow{2}{*}{$\begin{array}{c}\text { Non-red. } \\
\text { Sugars } \\
(\%)\end{array}$} & \multirow{2}{*}{$\begin{array}{c}\text { Total } \\
\text { sugar } \\
(\mathrm{cm})\end{array}$} & \multirow{2}{*}{$\begin{array}{c}\text { Ascorbi } \\
\text { c acid } \\
\text { (mg/100 } \\
9 \text { pulp) }\end{array}$} & \multirow{2}{*}{$\begin{array}{c}\text { Fruit } \\
\text { yield } \\
\text { (kg/tree) }\end{array}$} & \multicolumn{2}{|c|}{$\begin{array}{l}\text { Increased yield } \\
\text { over control }\end{array}$} \\
\hline & & & & & & & & $(\mathbf{k g})$ & $(\%)$ \\
\hline Control (water spray) & 8.55 & 2.42 & 2.37 & 1.85 & 4.22 & 525.10 & 76.80 & - & - \\
\hline $\mathrm{K}_{2} \mathrm{SO}_{4}(2 \%$ spray $)$ & 8.98 & 2.38 & 2.50 & 2.14 & 4.64 & 538.75 & 84.40 & 7.60 & 9.90 \\
\hline KCL (2\% spray) & 8.98 & 2.37 & 2.50 & 2.14 & 4.64 & 538.75 & 84.40 & 7.60 & 9.90 \\
\hline $\mathrm{KNO}_{3}(2 \%$ spray $)$ & 8.88 & 2.35 & 2.44 & 2.10 & 4.54 & 534.45 & 81.85 & 5.05 & 6.58 \\
\hline $\mathrm{K}_{2} \mathrm{SO}_{4}(2 \%)+\operatorname{urea}(2 \%)$ & 9.40 & 2.22 & 2.73 & 2.24 & 4.97 & 559.15 & 111.09 & 34.29 & 44.65 \\
\hline KCL $(2 \%)+$ urea $(2 \%)$ & 9.30 & 2.27 & 2.67 & 2.17 & 4.84 & 550.40 & 94.05 & 17.25 & 22.46 \\
\hline $\mathrm{KNO}_{3}(2 \%)+\operatorname{urea}(2 \%)$ & 9.15 & 2.32 & 2.60 & 2.15 & 4.75 & 543.30 & 91.60 & 14.80 & 19.27 \\
\hline Urea (2\% spray) & 9.10 & 2.34 & 2.58 & 2.14 & 4.72 & 541.30 & 90.60 & 13.80 & 17.97 \\
\hline S. Em. \pm & 0.15 & 0.03 & 0.03 & 0.02 & 0.06 & 4.48 & 3.77 & - & - \\
\hline C.D. $(P=0.05)$ & 0.44 & 0.09 & 0.10 & 0.07 & 0.19 & 13.58 & 11.43 & - & - \\
\hline
\end{tabular}

\section{Fruit quality}

The data furnished in Table-2 revealed that application of $\mathrm{K}_{2} \mathrm{SO}_{4}, \mathrm{KCL}$ or $\mathrm{KNO}_{3}$ could not affect the total soluble solids (TSS) or fruit acidity significantly when compared to control. These nutrients when sprayed with urea increased TSS and decreased fruit acidity significantly as compared to control treatment. 
It might be attributed to combined effect of sulphur, chlorine and nitrogen along with potassium on accumulation of higher level of water soluble compounds viz. total sugars, vitamins, and minerals which were synthesized, translocated and accumulated during fruit development and maturity stages because of certain chemical changes. Singh et al., (2009) also reported almost similar results. All treatments of nutrients spray significantly increased the percentage of reducing nonreducing and total sugars over control treatment. Among nutrients spray treatments, combined spray of $\mathrm{K}_{2} \mathrm{SO}_{4}+$ urea being at per with $\mathrm{KCL}+$ urea spray recorded significantly higher percentage of sugars than remaining all treatments. The reason may be explained due to the role of potassium in $\mathrm{CHO}$ synthesis, breakdown and translocation and synthesis of protein and neutralization of physiologically important organic acids. Ascorbic acid content in fruit increased significantly due to foliar spray of nutrients in all cases over control. Among those, $\mathrm{K}_{2} \mathrm{SO}_{4}+$ urea being at par with $\mathrm{KCL}+$ urea spray, recorded significantly higher level of ascorbic acid content in fruits than all other treatments. It might be the balanced foliar nutrition of potassium, sulphur, chlorine and nitrogen which perhaps improved the ascorbic acid content of fruits. It may be supported by the findings of Ali et al., (1993).

\section{Fruit yield}

It is visible from Table- 2 that the treatments of foliar spray of nutrients increased fruit yield per tree over control, but the foliar spray of only potassium sources could not record margin of yield increase to be significant. The combined spray of $\mathrm{K}_{2} \mathrm{SO}_{4}+$ urea recorded significantly highest of $111.09 \mathrm{~kg} /$ tree fruit yield which might be attributed to fruit retention per cent and weight of individual fruit. Combined spray of $\mathrm{KCL}+$ urea or $\mathrm{KNO}_{3}$ +urea or urea alone being at par yielded significantly higher fruit over control only.

The best treatment of, $\mathrm{K}_{2} \mathrm{SO}_{4}+$ urea spray recorded $34.29 \mathrm{~kg} /$ Tree or $44.65 \%$ higher fruit yield increase over control treatment of water spray. The best performance of $\mathrm{K}_{2} \mathrm{SO}_{4}+$ urea spray may be explained due to supplemental nutrition of potassium, sulphur and nitrogen through foliar application of nutrients which might has helped in increasing percentage of fruit retention and in proper development of individual fruit. These results are in conformity to the findings of Singh et al., (2009).

\section{References}

Ali, W., Pathak, R.A. and Yadav, A.L. 1993. Effect of foliar application of nutrients on guava (Psedium guajava L.) $\mathrm{Cv}$. Allahabad Safeda. Progressive Horticulture, 23(1-4): 14-21.

Khan, S., Singh, H.K., Vishwanath and Pratap, B. 2009. Influence of foliar feeding of nutrients and Thiourea on fruit yield and quality of aonlo (Emblica officinalis Gaertn) Cv. NA-6. Annals of Horticulture, 2(1): 89-91.

Panse, V.G., and Sukhatme, P.V. 1985. Randomized Blocks and Latin Square. Statistical Methods for Agricultural Workers, ICAR, New Delhi. Pp. 152-165.

Singh, D.M., Singh, H.K., Vishwanath and Pratap, B. 2009. Effect of foliar feeding of nutrients on yield and quality of aonla (Emblica Officinalis Gaertn.) fruits. Annals of Horticulture, 2(1): 95-97.

\section{How to cite this article:}

Jagendra Pratap Singh, Saurabh Tomar, Mahendra Chaudhary and Jayant Kumar Maurya. 2017. Yield and Quality of Aonla (Emblica officinalis Gaertn.) as Influenced by Foliar Application of Different Sources of Potassium with and without Urea Spray. Int.J.Curr.Microbiol.App.Sci. 6(9): 1530-1533. doi: https://doi.org/10.20546/ijcmas.2017.609.187 